\title{
Introduction to Electrical Engineering with Aim of Education for Generating and Motivating at Department of Electrical Engineering, Fukuoka Institute of Technology
}

\author{
Kazuhiro Ohyama Member, Toshinori Kajiwara Member, Kazuo Ikeda Non-member, \\ Kouichi Kudou Member, Toshinao Yamaguti Member, Keiji Matsuo Member, \\ Masaaki Imamura Member, Hidenori Kasiwazaki Non-member, Kenji Takahara Member, \\ Kaoru Takeda Member, Taro Tujino Non-member, Masaji Toyohuku Member, \\ Masaki Noguti Member, Masami Morooka Member, Takahisa Yamane Non-member \\ (Fukuoka Institute of Technology, ohyama@ee.fit.ac.jp)
}

Keyword : department of electrical engineering, education for generating and motivating, handicraft training

In this paper, "Introduction to Electrical Engineering" which is lecture and practical training subject with the aim of education for generating and motivating is described on the educational purpose, the detailed content of execution and effect after the execution. The results for 3 years of 2003, 2004 and 2005 are summarized. The future directivity of education for generating and motivating at Department of Electrical Engineering, Fukuoka Institute of Technology is discussed.

The introduction to Electrical Engineering is the subject whitch combines the lecture with the seminar. The contents of the lectures are recent topic of each application field of electrical engineering. The handicraft training is carried out in the seminar. The sutudens manufacture the electric vehicles using handmade DC motor in the handicraft training. The test of running for their works are carried out as a term examination. The various works were created. The

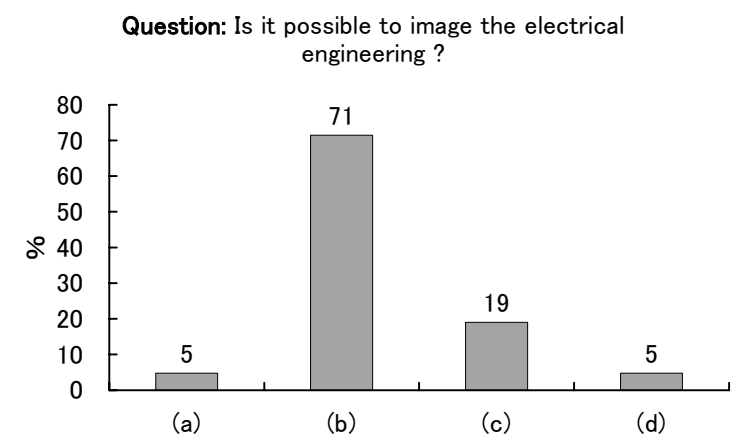

Fig. 1. Generation of image for electrical engineering ( (a) affirmation, (b) weak affirmation, (c) weak denial, (d) denial)

Question: Did you take the great interest to the electrical engineering after attending the introduction to electrical engineering ?

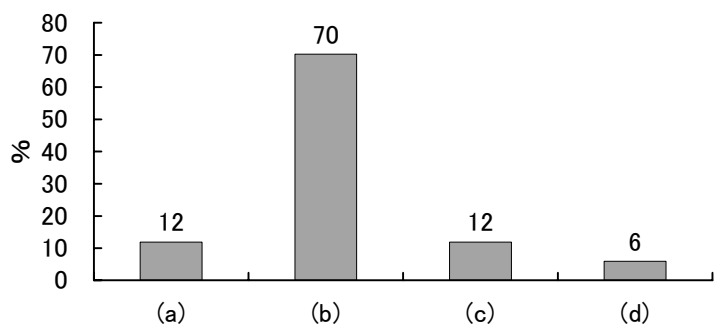

Fig. 2. Improvement in interest for electrical engineering ( (a) affirmation, (b) weak affirmation, (c) weak denial, (d) denial ) pictures of works are shown in the paper.

The information of the consciousness of the student is gathered by the questionnaire after the term examination. Figure 1 shows generation of image for electrical engineering. The affirmative opinion occupies $76 \%$. Most of students generate the image for electrical engineering. Figure 2 shows improvement in interest for electrical engineering. The affirmative opinion occupies $82 \%$. Most of students take the interest to electrical engineering. Figure 3 shows improvement in will to learn. The affirmative opinion occupies $83 \%$. Most of students have the motivation of learning after attending the introduction to electrical engineering. Figure 4 shows change of affirmative opinion. The affirmative opinion in Fig. 4 is the sum total of (a) and (b). The questionnaire results show that the effect of the education has been improved.

Also the contents of the lecture and seminar, other questionnaire results and discussions for them are shown in the paper.

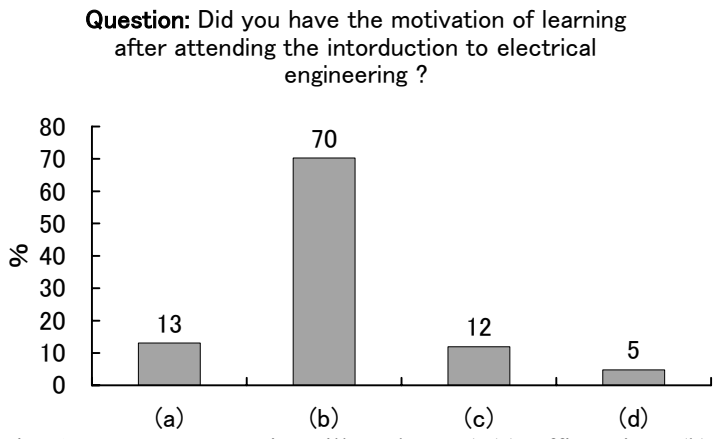

Fig. 3. Improvement in will to learn ( (a) affirmation, (b) weak affirmation, (c) weak denial, (d) denial )

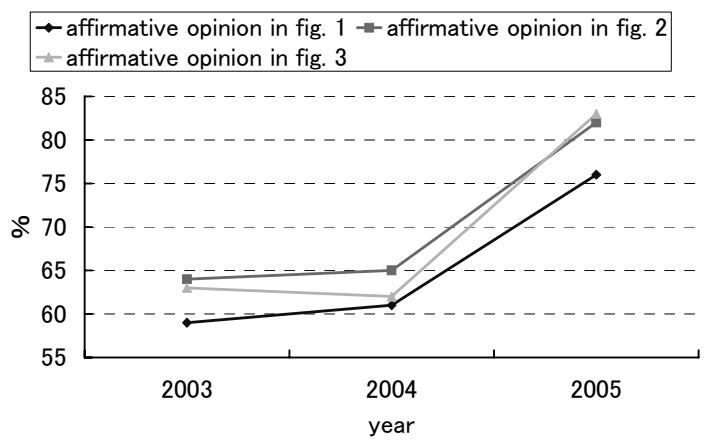

Fig. 4. Change of the affirmative opinion 


\section{福岡工業大学電気工学科の創成型・動機付教育 を目的とした電気工学概論}

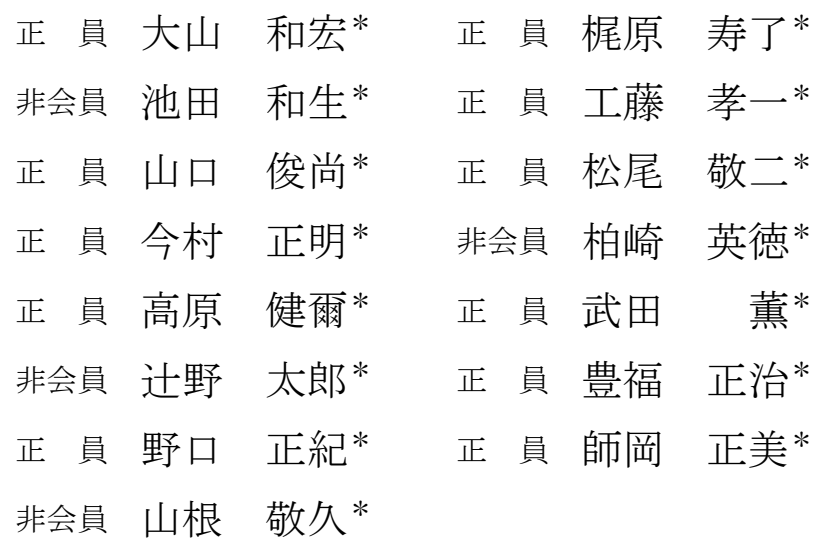

\section{Introduction to Electrical Engineering with Aim of Education for Generating and Motivating at Department of Electrical Engineering, Fukuoka Institute of Technology \\ Kazuhiro Ohyama*, Member, Toshinori Kajiwara*, Member, Kazuo Ikeda*, Non-member, Kouichi Kudou*, Member, \\ Toshinao Yamaguti*, Member, Keiji Matsuo*, Member, Masaaki Imamura*, Member, Hidenori Kasiwazaki*, Non-member, \\ Kenji Takahara*, Member, Kaoru Takeda*, Member, Taro Tujino*, Non-member, Masaji Toyohuku*, Member, Masanori Noguti*, Member, Masami Morooka*, Member, Takahisa Yamane*, Non-member}

In this paper, "Introduction to Electrical Engineering" which is lecture and practical training subject with the aim of education for generating and motivating is described on the educational purpose, the detailed content of execution and effect after the execution. The results for 3 years of 2003, 2004 and 2005 are summarized. The future directivity of education for generating and motivating at Department of Electrical Engineering, Fukuoka Institute of Technology is discussed.

キーワード : 電気工学科, 創成型・動機付教育, 工作実習

Keywords : department of electrical engineering, education for generating and motivating, handicraft training

\section{1. はじめに}

我が国では少子化の影響で，2007 年度より大学への実質 志願者倍率 1 倍, つまり大学全入時代に突入することが予 想される。また，2005 年度より，授業内容や授業時数を大 幅に削減した教育課程, いわゆる「ゆとり教育」を受けた 学生の大学への入学が開始した。このような社会状況にお いて, 大学進学者の基礎学力や学習意欲の低下が問題とな っている。特に, ごく平均的な学生の教育を担う大学では, これらの問題の影響は大きいと思われる。

当然ながら, 基礎学力や学習意欲の低下の問題は, 地方

福岡工業大学工学部電気工学科

T811-0295 福岡市東区和白東 3-30-1

Dept. of Electrical Eng., Fukuoka Institute of Technology

3-30-1, Wajirohigashi, Higashi-ku, Fukuoka 811-0295
の一私立大学である福岡工業大学においても共通の問題で ある。著者らは, 入学時の基礎学力や学習意欲に関わらず, 社会に貢献できる人材を育成できる教育システムを構築す ることが急務であると認識している。

福岡工業大学電気工学科では, 入学手続直後から始まる

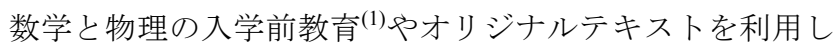
て進められる基礎教育科目の充実 ${ }^{(2)}$ により, 基礎学力の強化 を徹底して行っている。併せて，学習意欲の改善を行うた めに, 一年生の前期に「電気工学概論」を必修科目として 開講している。

この「電気工学概論」は, 創成型・動機付教育を目的と して考案され，2003 年度より開講されている。2003 年 9 月 の教育フロンティア研究会において, その概要と実施後の 効果, 幾つかの改善を要する点について報告した ${ }^{(3)} 。 2004$ 
年度は，改善を要する点の一つであった工作実習テーマの 改善に取り組んだ。2004 年 12 月の教育フロンティア研究会 において, 改善された工作実習テーマの詳細と実施後の効 果について報告した ${ }^{(4)}$ 。

本稿では,「電気工学概論」の教育目的, 詳細な実施内容, 実施後の教育効果について述べる。2005 年度実施分を含む 3 年間の成果を総括するとともに, 本学科における創成型・ 動機付教育の今後の方向性について議論する。

\section{2. 教育目的}

学習意欲低下の理由として, 新入生の大学進学に対する 目的意識の変化が考えられる。「無目的」や「無気力」の学 生を含め, 電気工学科入入学してくる学生が必ずしも電気 工学というものを良く理解し, 電気工学に対する高い学習 意欲を有しているわけではない。そこで，早い時期に電気 工学を概観させることで電気工学への興味を喚起し, 電気 技術者になることが，大学進学の第一目的であると認識さ せる必要がある。福岡工業大学電気工学科では, 新入生の 電気工学への興味の喚起を目的として, 2003 年度より「電 気工学概論」を開講している。この「電気工学概論」は, 講義と少人数ゼミを組み合わせた変則的な科目である。

〈2·1〉講義講義は, 受講生に進路について考えさ せ， 4 年間の学習計画を立案させることを目的としている。 全講義回数の約半分を利用し, オムニバス形式の講義を行 っている。2005 年度実施の講義テーマは以下の通りである。

(1) 電気工学を学ぶにあたって

(2) 電気機器関連分野の最近の話題

（3）情報制御関連分野の最近の話題

(4) 電気エネルギー関連分野の最近の話題

(5) 半導体関連分野の最近の話題

(6) 実社会の電気工学

2004 年度は, 2003 年度では単独で実施していた講義テー マ「電気工学関連の資格について」を「(1)電気工学を学ぶ にあたって」に統合した。内容的にも時間的にも，(1)に含 めることが可能であることが，統合の理由である。また， 電気工学をよりバランス良く説明するために「(5)半導体分 野の最近の話題」を追加した。2005 年度は, 講義を担当す る教員で FD を実施し，授業全般に対する意見交換を行っ た。様々な意見を集約し，パワーポイントを利用した分か り易いプレゼンテーション, 配布資料の作成, 履修モデル の提示等を行うことを申し合わせた。

講義テーマは, 電気工学科卒業後の就職先を強く意識し たものとなっている。「(1)電気工学を学ぶにあたって」で は，カリキュラムの基本的な説明に始まり，講義を受ける ときの心構え, 在学中に取り組むべきことなど, 全般的な 説明を行う。(2)から(5)の「各関連分野の最近の話題」で は, 電気工学を学んだ上で活躍できる各関連分野を具体的 に示し，その関連分野で活躍するために必要な在学中の準 備を示唆する。また,「(6)実社会の電気工学」では, 電気 工学科の卒業生に講演して貪い, より臨場感を持って 4 年
後の就職をイメージさせる。各関連分野を説明する内容の 詳細については, 担当教員に任せている。ただし, (2)から (5)の「各関連分野の最近の話題」を担当する教員は, シラ バスや履修フローチャートを参照し, 担当する関連分野を 重視した場合の履修方法を指導するように申し合わせてい る。

〈2·2〉 少人数ゼミ 全講義回数の約半分を利用し, 少人数ゼミを行っている。電気工学を初めて学ぶ新入生に とって, 座学講義のみにより電気工学をイメージし, その 面白さを理解することは難しい。そこで, 座学講義と併せ て, 担当教員 1 名, 受講生 7 名で構成する少人数ゼミを実 施している。少人数ゼミでは, 実体験を交えて電気工学の 面白さを理解させるために, 工作実習を行っている。また, 少人数ゼミ形式の採用は, 新入生との連絡を密にし, 留年 や退学に至る前に指導を行うことを狙いとしている。

\section{3. 工作実習}

実体験を交えて電気工学の面白さを理解させるために, 工作実習を行っている。工作実習では, 1 名の受講生につき 1 つの作品を仕上げることを義務付けている。2003 年度の 工作実習テーマとして，「株式会社タミヤ製ミ二四駆」を採 用した。具体的には，規定時間内に「株式会社タミヤ製ミ 二四駆」を製作させ，タミヤ公認競技会規則に準拠した競 技会を開催し, 走行タイムを競わせた。講義終了後の授業 アンケートや担当教員らで行った反省会において, 以下の 問題点が挙げられた。

（1）タミヤ製ミ二四駆の完成度が高いため, 車体の軽量 化やパーツの交換など, 表面的な改良しか加えることがで きない。そのため, 大学生相当の創意工夫する能力を養う ことが難しい。

（2）使用している直流モータは, 一度分解寸ると組み直 すことが困難であることから，実質的にブラックボックス 化している。そのため, 電気工学の身近な応用例として, 構造や原理の説明に利用することが難しい。

以上の問題点を解決するために, 2004 年度の工作実習テ 一マとして，「手作りモータによる電気自動車製作」を採用 した。2003 年度の問題点は解消されたが, 講義終了後の授 業アンケートにおいて, 工作実習テーマが難しくなり，規 定時間内に製作を終了できなかった学生らから，モータに 関する専門知識が不十分な状態で工作自習を行うことに対 する不満が聞かれた。そこで，2005 年度は，2004 年度と同 じ工作実習テーマを採用し，ガイダンスや製作に使用する 材料を更に充実させて実施した。

〈3・1〉工作実習テーマ初回の工作自習においてガ イダンスを行い, 直流モータの動作原理について説明し, 最も簡単と思われる製作例を紹介する。図 1 に紹介した製 作例を示す。直流モータの電機子は, ペットボトルのキャ ップ 2 個を貼り合わせた円筒にスロット 2 個を設け, 集中 巻によりホルマル線を巻くことで実現している。界磁は, 与えられた 4 個の永久磁石のうち 2 個を, 磁力を強めるた 
めに直列に張り合わせ，それぞれ界磁の $\mathrm{N}$ 極と $\mathrm{S}$ 極とし， シャーシであるバルサ材に直接固定することで得ている。 ブラシと整流子には，スチール缶を切り，サンドペーパー で絶縁を剥がしたものを使用している。ブラシは，シャー シに直接固定されている。整流子は, 回転軸に固定された ペットボトルのキャップの表面に接着剤で貼り付けられて いる。タイヤは, ペットボトルのキャップ 2 個を貼り合わ せた円筒を使用し，回転軸に直結している。また，シャー シを地面から浮かすために, タイヤにビニールテープを巻 いている。

図 1 の製作例は, 平坦地での走行は可能であるが, 坂や カーブを含む競技会コースでは完走できない。ガイダンス では，予め，製作例と同じものを製作しても，十分な性能 が得られないことを説明し, 創意工夫することが必須であ ることを強調する。ガイダンス終了後, 製作例を製作する に当たり, 最低限必要と思われる材料と工具を配布し, 少 人数ゼミに分かれ，工作実習を開始する。表 1 に配布した 材料を, 表 2 に貸し出した工具を示す。製作のルールとし て, ホルマル線, 充電式電池, 永久磁石は, 配布された分 のみを使用し，それぞれを追加することを禁止している。 また，模型メーカーや機械部品メーカーより販売されてい るタイヤやギアなどの専用パーツの使用を禁止し, 身近な 材料を使用し，自ら加工すること促している。

ガイダンスで紹介する製作例が直流モータを前提として いることもあり，特に制限は行っていないが，これまで交

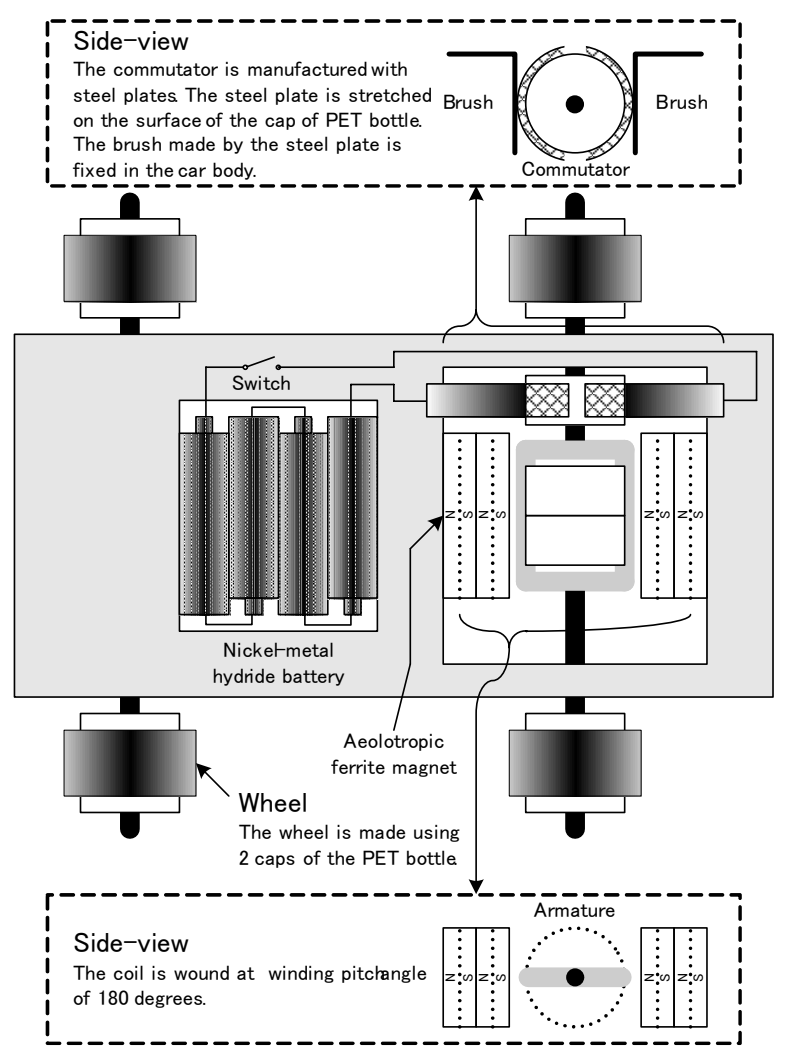

図 1 製作例

Fig. 1. Example of manufacture.
流モータを製作した例は見られない。交流モータを製作す る場合はドライバの製作等も必要となり, 技術的なハード ルが急に上がるので, 1 年生の前期においての製作は困難で あると考える。

直流モータの採用を前提として, どの程度の創意工夫の 幅があるのか考察してみる。直流モータの界磁において, 配布する永久磁石の形状と数量を考慮すると, 極数は 2 ま たは 4 を選択できる。また, 極数 2 を選択し, 永久磁石を 4 個使用寸る場合, 磁石配置として直列または並列を選択で きる。整流子やスロットを全て手作りすることを考慮する と, 電機子コイル数は 2 から 4 が適当である。以上を鑑み ると, 図 2 に示すように, 界磁と電機子の組み合わせによ り, 12 種類の構成が考えられる。また, 直流モータの動力 をタイヤに伝達する機構として, 直流モータの回転軸にタ イヤを直接固定する直結方式, ギア変速機を用いるギア変 速方式，ゴムなどの摩擦力のみを利用して変速するゴム変

\section{表 1 工作実習のための材料（1 名分）}

Table 1. Materials for handicraft training of one student.

\begin{tabular}{|l|l|c|}
\hline \multicolumn{1}{|c|}{ Name of material } & Quantity & Specification \\
\hline Board of balsa wood & 1 & $20 \times 100 \times 150 \mathrm{~mm}$ \\
\hline Zinced steel plate & 1 & - \\
\hline Phosphor bronze & 1 & - \\
\hline Copper & 1 & - \\
\hline Polyester enamel copper wire & 1 & $\Phi 0.32 \mathrm{~mm}$ \\
\hline Nickel-Metal hydride battery & 4 & $2150 \mathrm{~mA}, 1.2 \mathrm{~V}$ \\
\hline Battery socket & 1 & series of four batteries \\
\hline Aeolotropic ferrite magnet & 4 & $40 \times 20 \times 10 \mathrm{~mm}$ \\
\hline Round bar of ramin wood & 1 & $\Phi 5 \mathrm{~mm}$ \\
\hline Mechanical switch & 1 & On and off only \\
\hline Vinyl tape & 1 & $10 \mathrm{~m}$ \\
\hline Adhesive & 1 & $10 \mathrm{ml}$ \\
\hline
\end{tabular}

表 2 工作実習のための工具（7名分）

Table 2. Tools for handicraft training of 7 students.

\begin{tabular}{|l|l|l|}
\hline \multicolumn{1}{|c|}{ Name of tool } & Quantity & \multicolumn{1}{c|}{ Specification } \\
\hline Cutter knife & 7 & - \\
\hline Edge of cutter knife & 1 & Set of 10 edges \\
\hline Diagonal cutting pliers & 2 & - \\
\hline Small size screwdrivers & 1 & Set of 6 screwdrivers \\
\hline Normal size screwdrivers & 1 & Set of 8 screwdrivers \\
\hline Side cutting pliers & 1 & $150 \mathrm{~mm}$ \\
\hline Long nose pliers & 1 & $150 \mathrm{~mm}$ \\
\hline Tweezers & 1 & \\
\hline Edge of manual drill & 1 & Set of 13 edges \\
\hline Calipers & 1 & $100 \mathrm{~mm}$ \\
\hline Tape measure & 1 & $5.5 \mathrm{~m}$ \\
\hline Thread saw & 1 & woodwork only \\
\hline Rubber hammer & 1 & - \\
\hline File & 1 & metal work only \\
\hline Sandpaper & 7 & woodwork only \\
\hline Hexagon wrench & 1 & Set of 8 wrenches \\
\hline Extension electrical cord & 1 & 6 plug sockets, $1.5 \mathrm{~m}$ \\
\hline Battery charger & 3 & \\
\hline Scissors & 7 & metal work only \\
\hline Soldering iron & 2 & $100 \mathrm{~V}, 15 \mathrm{~W}$ \\
\hline Solder & 2 & \\
\hline
\end{tabular}


速方式，プーリーとベルトを利用したベルト変速方式など が考えられる。他にも, タイヤに動力を直接伝達せずに, プロペラを利用して間接的に推進力を得る方法も考えられ る。上述のことを考慮すると, 様々な創意工夫やアイディ アを盛り込むことが可能であり，創成型教育を目的とした 工作実習のテーマとして，妥当なものと思われる。

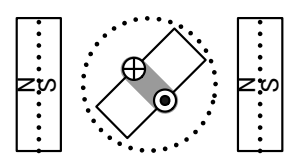

(a) 2 poles, winding pitch angle of 180 degrees

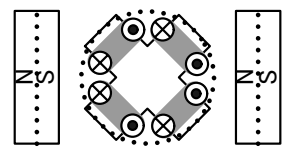

(c) 2 poles, winding pitch angle of 90 degrees

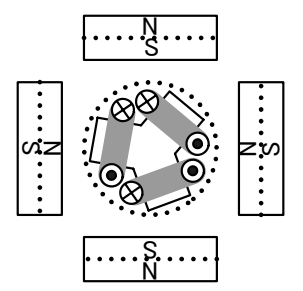

(e) 4 poles, winding pitch angle of 120 degrees

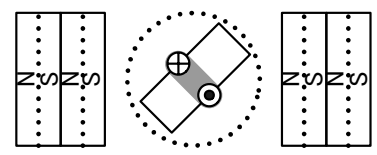

(g) 2 series poles, winding pitch angle of 180 degrees

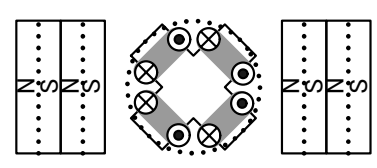

(i) 2 series poles, winding pitch angle of 90 degrees

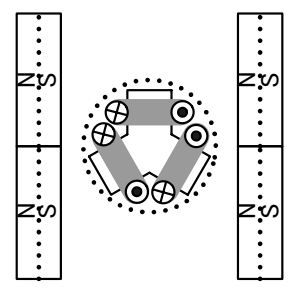

(k) 2 parallel poles, winding pitch angle of 120 degrees

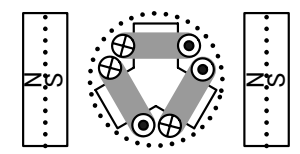

(b) 2 poles, winding pitch angle of 120 degrees

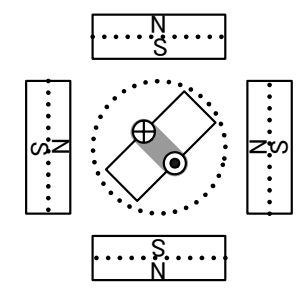

(d) 4 poles, winding pitch angle of 180 degrees

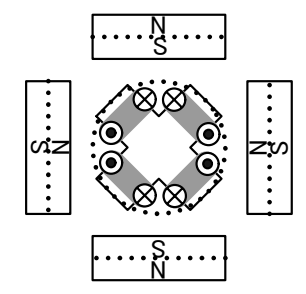

(f) 4 poles, winding pitch angle of 90 degrees

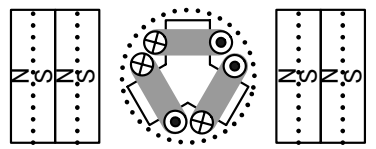

(h) 2 series poles, winding pitch angle of 120 degrees
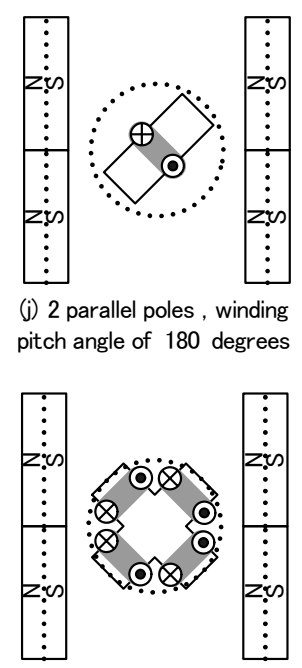

(I) 2 parallel poles, winding pitch angle of 90 degrees

図 2 界磁と電機子の組み合わせ

Fig. 2. Combinations of armature and field system.
直流モータの製作は, 電気工学に対する興味を喚起し, 電気工学について考えさせる良い題材である。例えば，電 池の内部抵抗とブラシ抵抗と電機子コイル抵抗の関係を電 気回路的に考察すると, 使用することが義務付けられてい るホルマル線 $(\phi 0.32 \mathrm{~mm})$ では, 単線ではなく複線で巻い た方が電機子コイルの起磁力が増加することが分かる。ま た，材料面の工夫として，電機子を空心とせず，鉄心を用 いるとコイルとの鎖交磁束が増え, トルクが増加する。そ の他, ギャップの最適化, 電機子形状の工夫など, 取り組 むべき課題は数多く存在する。

〈3·2〉 作品例 鉄心材料として, 亜鉛引き鉄板を提 供した。整流子材料として, 電気抵抗が小さく塑性の良い 銅を提供した。ブラシ材料として，電気抵抗が小さくばね 性に優れたりん青銅を提供した。殆どの受講生が，それら の材料を適宜選択して使用していた。期待したとおり, 様々 な創意工夫やアイディアを盛り込んだ作品が生まれた。図 3 に作品例を示す。ここで紹介する作品は，2005 年度におい て, 受講生や担当教員が製作したものである。受講生の多 くが，競技会までの製作期限を意識し，製作が比較的容易 である, 界磁 2 極・巻線ピッチ角 180 度, または界磁 2 極・ 巻線ピッチ角 120 度の直流モー夕を採用していた。図 3 か ら図 6 において, 個別に作品を解説する。競技会上位入賞 者の作品を保管しているが, その中で, 界磁 2 極・巻線ピ ッチ角 90 度, または界磁 4 極・巻線ピッチ角 90 度の直流 モータを採用した例がなかった。そこで, 担当教員の作品 も含めて紹介することにする。

図 3(a)の作品は, 界磁 2 極, 巻線ピッチ 180 度を採用した 例である。亜鉛引き鉄板を曲げ加工し, ラミン丸棒に固定 することで回転子鉄心を製作し，ビニールテープで絶縁を 施した後, ホルマル線を複線にて巻くことで電機子を製作 している。製作者は複線にて巻線を製作することで電機子 抵抗と誘起電圧が小さくなり, 電池の内部抵抗とのバラン スが良くなることを実験的に確かめている。この例は，い わゆる 2 極モータであり, 鉄心構造が簡単で, 整流子製作 も容易である。しかし，リラクタンストルクが大きい上に， 始動トルクが零となるため始動性に問題がある。そこで, 製作者は電機子鉄心を非対称な形状になるように加工し, 自己始動が行えるように工夫している。動力を伝達する機 構として直結方式が採用されている。そこで, 製作者は直 結方式でのトルク不足を補うために, なるべくタイヤ径を 小さくする工夫を行っている。

図 3(b)の作品も, 界磁 2 極, 巻線ピッチ 180 度を採用して いる。電機子は，基本的に同図(a)と同じ方法で製作されて いるが，単線でコイルが巻かれている点が異なる。透明な プラスチックを加工し，見た目にも美しい固定子枠を作成 している。シャーシと直流モータが独立しているうえに, 固定子わくが透明な材料で製作されている。これは, 直流 モータの動作原理を考察し易いように, 担当教員が行った 工夫である。動力を伝達する機構としてゴム変速方式が採 用されている。 
図 3(c)の作品も, 界磁 2 極, 巻線ピッチ 180 度を採用して いる。電機子は, 基本的に同図(a)と同じ方法で製作されて いるが, 鉄心材料としてビスが使用されている点, 単線で コイルが巻かれている点が異なる。カメラのフィルムケー スを加工し, 固定子枠を作成している。アルミでシャーシ を製作することで強度を持たせ，全てがコンパクトにまと められ, 軽量化されている。動力を伝達する機構として,

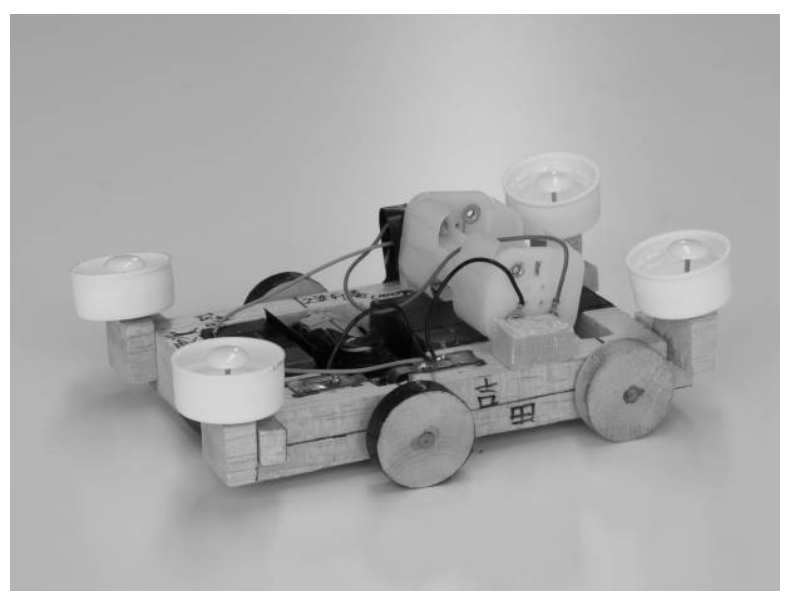

(a)

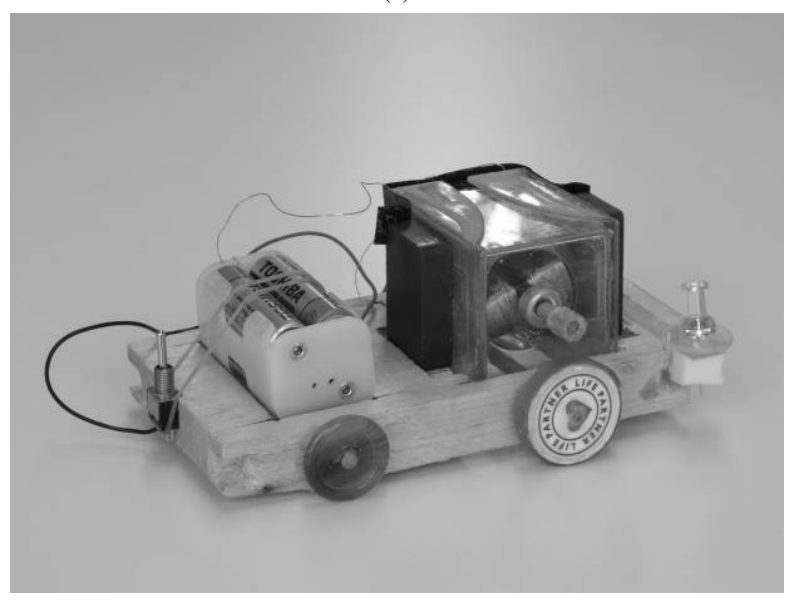

(b)

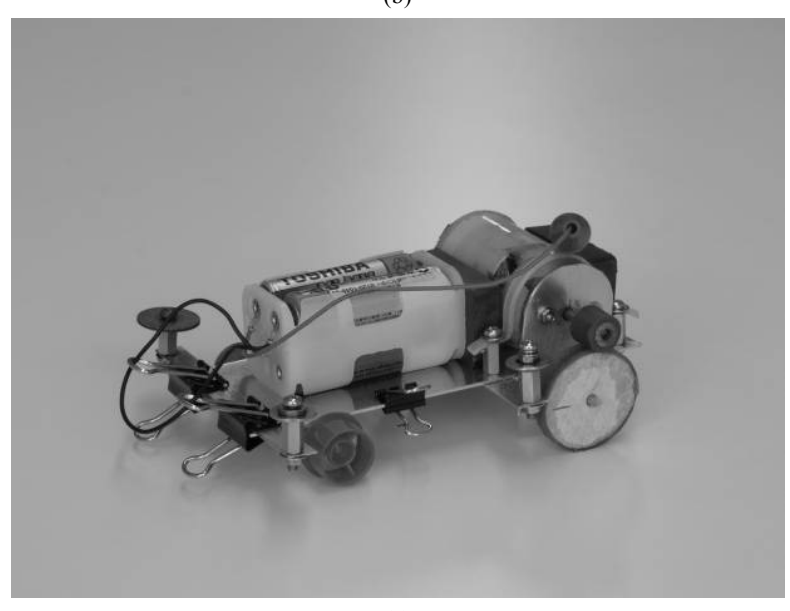

(c)

図 3 界磁 2 極, 巻線ピッチ角 180 度の作品例 Fig. 3. Examples of production for 2 poles and winding pitch angle of 180 degrees.
車重で連結されるクラッチを組み込んだゴム変速方式が採 用されている。車重で連結されるクラッチは, 変速機の回 転軸中心の加工精度が悪いことに対する工夫である。

図 4(a)の作品は, 直列界磁 2 極, 巻線ピッチ 120 度を採用 した例である。模型用小形モータにおいて実績の高い界磁 と電機子の組み合わせである。亜鉛引き鉄板を曲げ加工し, ラミン丸棒に固定することで鉄心を作成し，ビニールテー プで絶縁を施した上で, ホルマル線を複線にて巻くことで 電機子を作成している。直列界磁 2 極を採用すると, リラ クタンストルクが大きくなり過ぎるので, 自己始動が難し い。そこで，製作者は，自己始動できるように，ギャップ を最適化している。動力を伝達する機構として直結方式が 採用されている。図 3(a)の作品と同様に, 製作者は直結方式 でのトルク不足を補うために, なるべくタイヤ径を小さく する工夫を行っている。この作品が競技会において優勝し た。また，この作品と類似した作品が良い成績を修めてい る。

図 4(b)の作品も, 界磁 2 極, 巻線ピッチ 120 度を採用して いる。電機子は，基本的に同図(a)と同じ方法で製作されて いるが, 鉄心が積層構造である点, 単線でコイルが巻かれ

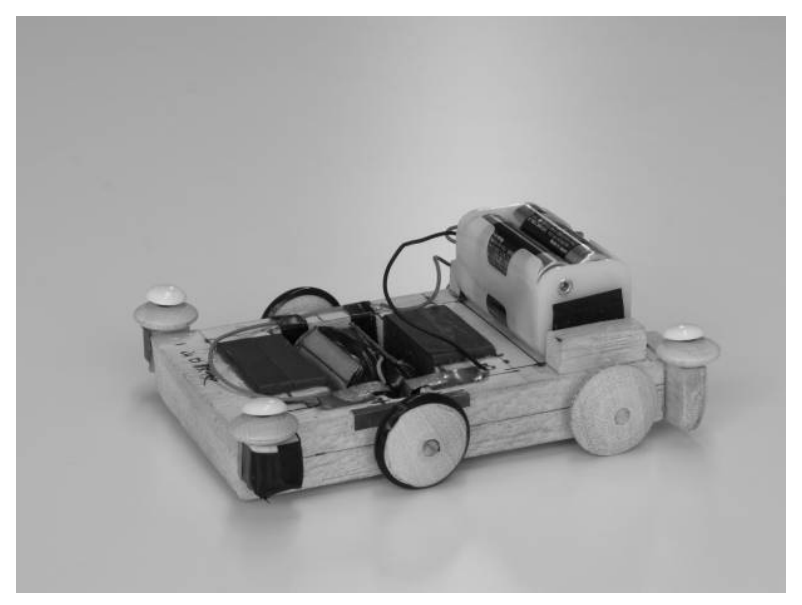

(a)

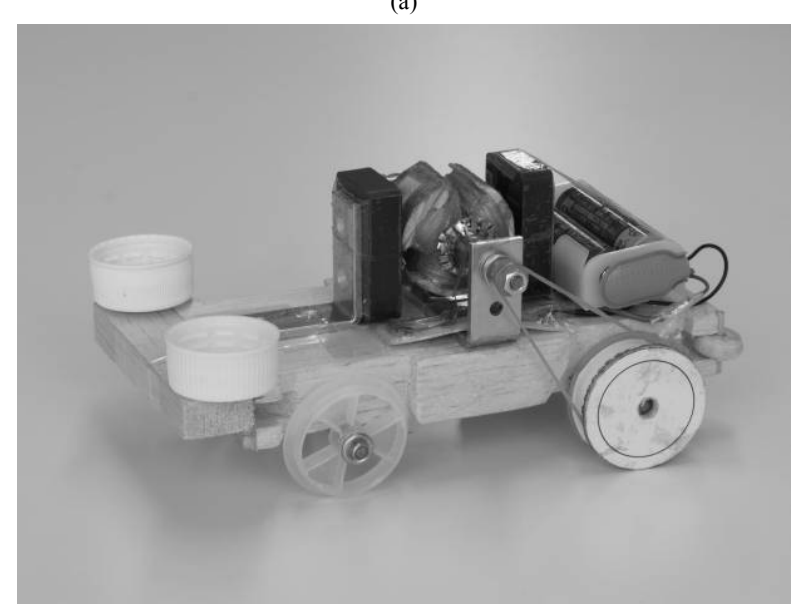

(b)

図 4 界磁 2 極, 巻線ピッチ角 120 度の作品例 Fig. 4. Examples of production for 2 poles and winding pitch angle of 180 degrees. 
ている点が異なる。製作者は, 模型用小形モータを分解し 図面を起こすことで，模型用小形モータの鉄心形状を忠実 に再現しているため, リラクタンストルクが小さく抑えら れ，滑らかな回転が得られている。動力を伝達する機構と して, ベルト変速方式が採用されている。

図 5(a)の作品は，界磁 2 極，巻線ピッチ 90 度を採用した 例である。亜鉛引き鉄板とマニラ紙を交互に張り合わせて 回転子鉄心を製作し，ホルマル線を単線にて巻くことで電 機子を製作している。コイル 4 個のうち 2 個の整流は， 180 度ごとに正負切り換わる同じ整流子とブラシで行える。し

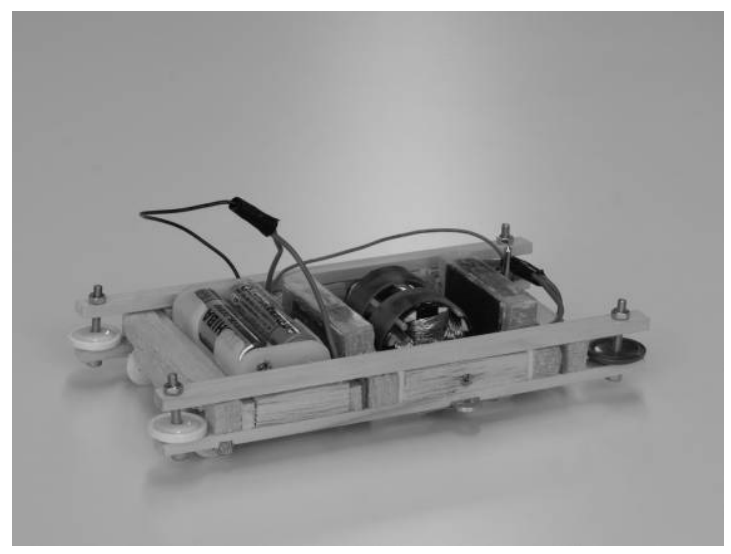

(a)

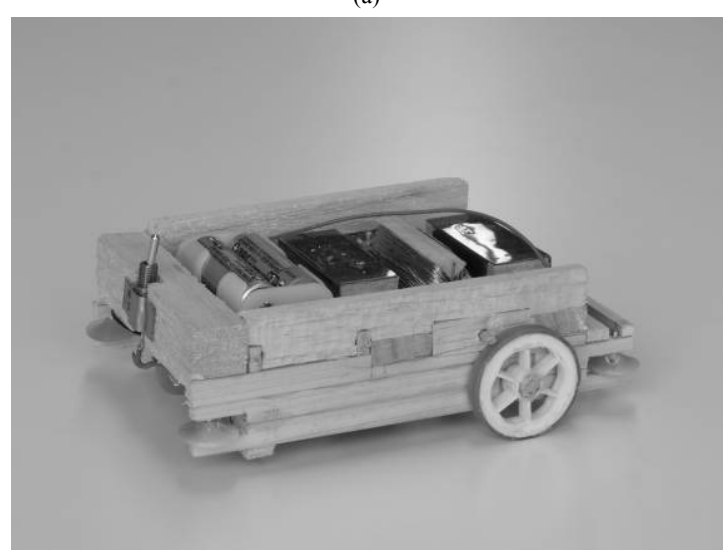

(b)

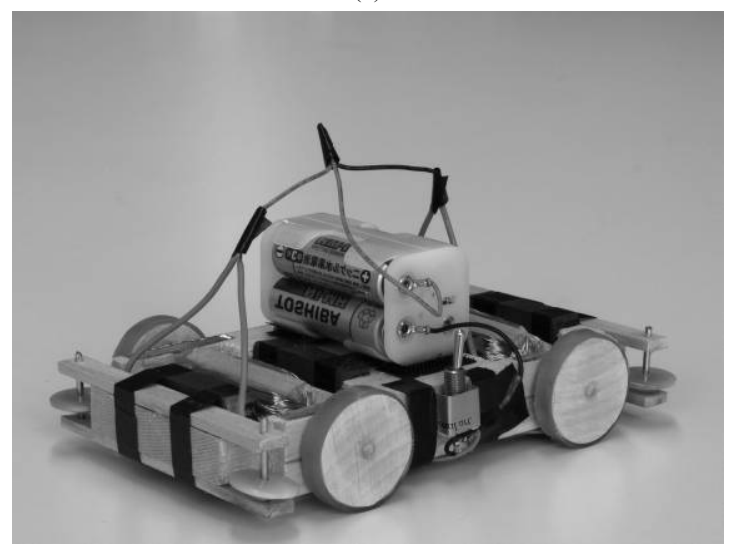

(c)

図 5 界磁 2 極, 巻線ピッチ 90 度の作品例

Fig. 5. Examples of production for 2 poles and winding pitch angle of 90 degrees.
かし，他の 2 個は，それらと 90 度の位相差がある別の整流 子とブラシで整流を行う必要がある。そこで, 回転軸の両 端を利用することで，2 組の整流子とブラシを設置してい る。動力を伝達する機構として, 電機子自体にゴムを貼り 付けて駆動輪とした直結方式が採用されている。製作者は, 直結方式でのトルク不足を補うために, 電機子をタイヤと して使用し，回転半径を極限まで小さくする工夫を行って いる。

図 5(b)の作品も, 直列界磁 2 極, 巻線ピッチ 90 度を採用 した例である。回転子は木材を加工して作成しているので, いわゆる空心である。リラクタンストルクが存在しないの で, ギャップは極力小さく調整されている。同図(a)と同様 に 2 組の整流子とブラシが必要である。そこで，製作者は， 回転軸の片方に 90 度の位相差を持つ整流子を二重にして設 置し, 共通のブラシを使用する工夫を行っている。動力を 伝達する機構として, 木材とプラスチックを丁寧に加工し て製作したギアを使用したギア変速方式が採用されてい る。

図 5(c)の作品も, 界磁 2 極, 巻線ピッチ 90 度を採用した 例である。図 5(a) と同じ方法で電機子が製作されている。ま た，図 5(b)と同じ方法で整流子とブラシが設置されている。 製作者は, 永久磁石の利用率を上げるために, 前後輪に同 じ直流モータを設け, 四輪駆動としている。動力を伝達す る機構として直結方式が採用されている。

図 6 の作品は, 界磁 4 極, 巻線ピッチ 90 度を採用した例 である。亜鉛引き鉄板とマニラ紙を交互に張り合わせて鉄 心を作成し, ホルマル線を単線にて巻くことで電機子を作 成している。全てのコイルが 90 度ごとに正負切り換わるの で，2組のブラシが必要となる。しかし，2 組のブラシを回 転軸の片方に設置することが困難である。そこで, 製作者 は，回転軸の両端を利用することで，2組のブラシを設置す る工夫を行っている。動力を伝達する機構としてゴム変速 方式が採用されている。

〈3.3〉 中間発表 少人数ゼミ 7 時間のうち 1 時間を 利用して中間発表を行う。中間発表は, 発表時間 6 分, 質

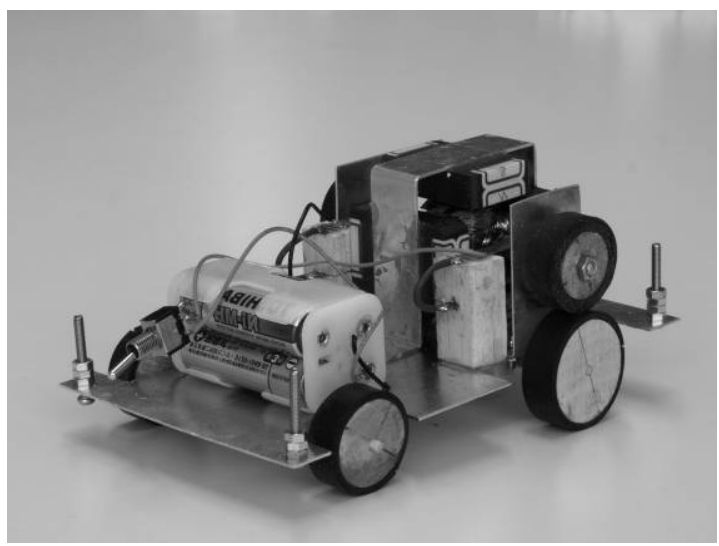

図 6 界磁 4 極, 巻線ピッチ 90 度の作品例

Fig. 6. Examples of production for 4 poles and winding pitch angle of 90 degrees. 
疑応答 4 分の要領で, 7 人全員が行う。工作実習の初回のガ イダンスにおいて, 少人数ゼミごとに中間発表を開催する ことをアナウンスする。また, 中間発表では, 製作中の作 品の設計やアイディア, 進捗状況, 工作実習終了までの計 画を発表するように指導する。中間発表では, マイクロソ フト社パワーポイントの使用を義務付けている。パワーポ イントの基本的な使用方法については, 1 年前期で開講され る「コンピュータリテラシー」で説明している。

〈3.4〉 報告書 工作実習が終了するまでに，製作し た電気自動車に関する報告書を作成させる。工作実習の初 回のガイダンスにおいて, 工作実習終了までに少人数ゼミ の担当教員へ報告書を提出するようにアナウンスする。ま た, モータ設計, 電気回路設計, シャーシ設計の各項目に ついて, 図などを適宜用いて, 丁寧に分かり易く説明する ように指導する。

〈3.5〉 成績評価成績は, 出席, 中間発表, 報告書, 競技会などを考慮して総合的に評価する。満点に占める各 評価の割合は, 出席を 28 点, 報告書を 5 点, 中間発表を 10 点, 競技会を 57 点としている。

中間発表と報告書の成績については, 少人数ゼミの担当 教員が担当する学生を評価する。具体的に中間発表では, 発表自体に対して, 以下の 3 項目を評価する。

(1) 内容：スライドや検討考察への評価を行う。

(2) 技術: 発表に相応しい日本語の評価を行う。

(3) 説得力: 説明能力や説明の論理性を評価する。

また, 質疑応答に対して, 以下の 2 項目を評価する。

(4) 態度：質問に対する理解と対処への評価を行う。

（5）明快さ：質問に対する回答の適切さを評価する。

具体的に報告書では, モータ設計, 電気回路設計, シャ ーシ設計の各項目に対して, 説明は明確に行われているか, 図表は丁寧に描かれているか，等を評価する。担当教員間 の評価基準を統一するため, 上述の評価項目に対して 5 段 階評価を行う書式を配布し，それを使用して評価すること を義務付け, 平均的な学生が 6 割の得点率となるように申 し合わせを行っている。

競技会の成績は, 直流モータが回転したら 30 点, 平坦地 での走行距離測定により $5[\mathrm{~m}]$ 未満であれば 7 点, $15[\mathrm{~m}]$ 以上 であれば満点 15 点としている。走行距離が $15[\mathrm{~m}]$ 以上の場 合, 全長 $24[\mathrm{~m}]$ の競技用コースを走行し, 走行距離が 1 位の 学生の点数を満点 12 点とし, その他の学生の点数は走行距 離に比例して計算する。競技用コースは，タミヤ製ミ二四 駆用オーバルコース 3 セットを組み合わせたものである。 競技用コースには坂やカーブがあり, 多数の作品の走行距 離が零となることから，平坦地での走行距離の測定を併用 している。2005 年度においては, 多数の学生が競技用コー スを完走したため, 完走した学生全員に満点 12 点を与え, 走行タイムで優勝者を決定した。

\section{4. 教育効果}

〈4·1〉講義＼cjkstart図 7 に2005 年度における講義への感想

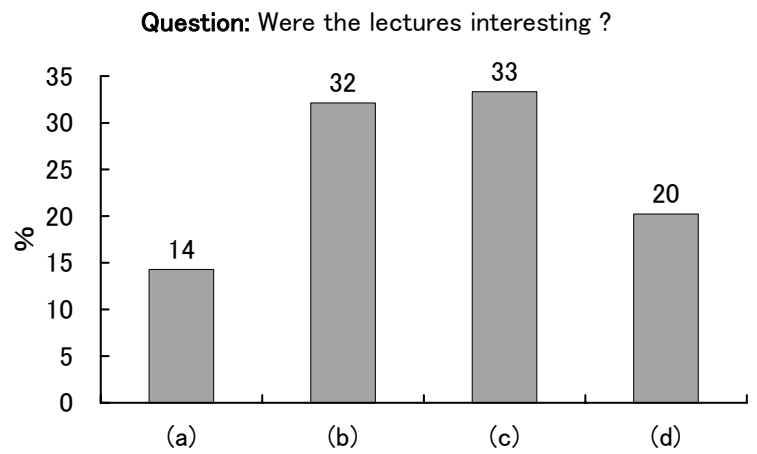

図 7 講義の感想（(a)肯定, (b)弱い肯定, (c)弱い否定, (d)否定)

Fig. 7. Impression of lecture ( (a) affirmation, (b) weak affirmation, (c) weak denial, (d) denial ).

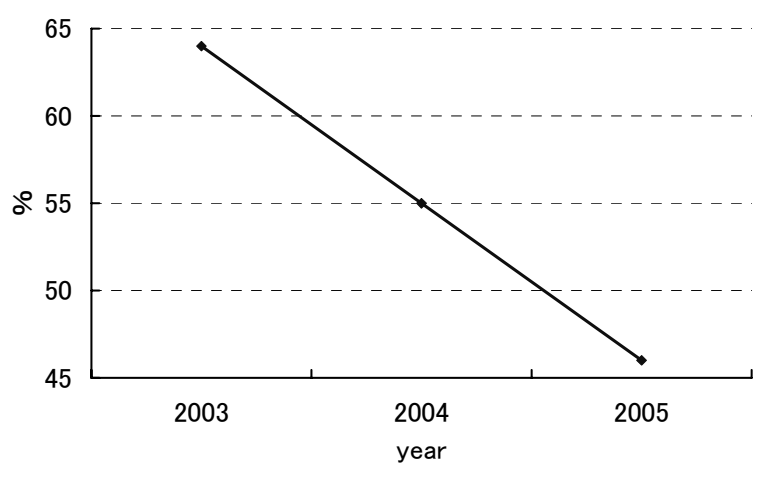

図 8 講義への感想における肯定的な意見の変化

Fig. 8. Change of affirmative opinion for impression of lecture.

を示す。図 8 に講義への感想における肯定的な意見の変化 を示す。 2005 年度の肯定的な意見（肯定「そう思う」, 弱い 肯定「どちらかと言えば，そう思う」の合計）は 46\%であ った。ほぼ半数の学生が肯定的であった。2003 年度, 2004 年度と年度を重初るごとに確実に内容が充実してきている はずだが，逆に肯定的な意見の割合は減少傾向にある。し かし，2005 年度に関しては, 受講生の意識変化において良 い効果が見られた。詳しくは $\langle 4 \cdot 3\rangle$ 節で述べる。

本学において, 肯定的な意見が 5 割なのは, ごく平均的 な評価である。しかし, 受講生の電気工学への興味を喚起 し, 学習意欲を高めるという本来の目的を達成するために は，更なる授業改善が必要である。

〈4·2〉少人数ゼミ図9に2005 年度における工作実 習への感想を示す。図 10 に工作実習への感想における肯定 的な意見の変化を示す。 2005 年度の 7 割の学生が肯定的で あった。しかし， 2003 年度と比較し 2004 年度は肯定的な意 見が 2 割も減少した。肯定的な意見の減少は, 2003 年度に 比べ, 工作実習のテーマが難しくなり, 工作実習を楽しむ 余裕のない学生が増えたのが原因であると分析した。そこ で，2005 年度は工作実習ガイダンスや配布材料の充実を行 った。肯定的な意見の割合は, 2004 年度とほぼ同じであっ 


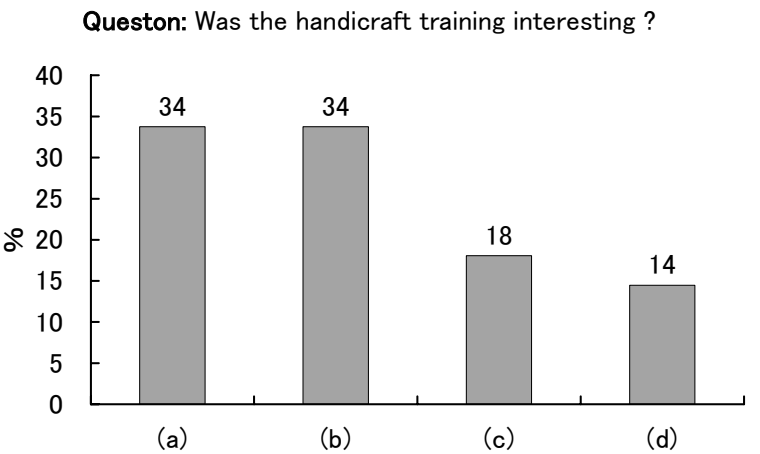

図 9 工作実習への感想（(a)肯定，(b)弱い肯定, (c)弱い否定, (d)否定)

Fig. 9. Impression of handicraft practical training ( (a) affirmation, (b) weak affirmation, (c) weak denial, (d) denial ).

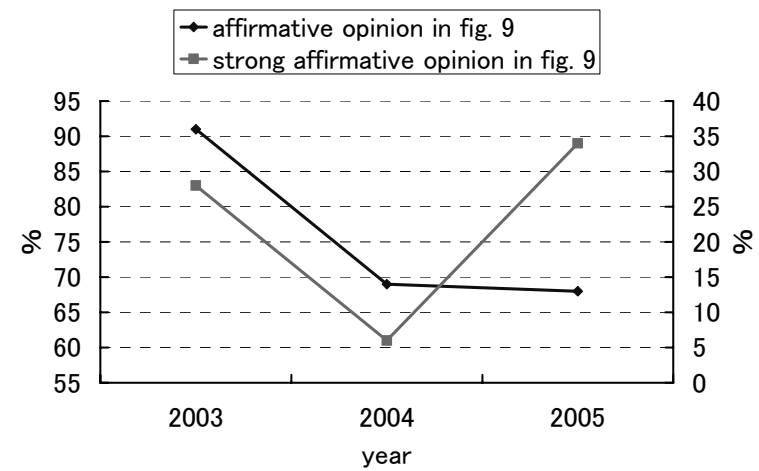

図 10 工作実習への感想における肯定的な意見の変化

Fig. 10. Change of affirmative opinion for impression of handicraft practical training.

たが, 完全な肯定「そう思う」の割合が大幅に増えたので, それらの効果は大きかったと分析する。

\section{$\langle 4 \cdot 3\rangle \quad$ 受講生の意識変化}

$\langle 4 \cdot 3 \cdot 1\rangle$ 各年度間の比較図 11 に 2005 年度におけ る電気工学科を選んだ理由を示す。図 12 に電気工学の習得 を目的とした学生の変化を示す。年度を負うごとに, 電気 工学の習得を目的とした学生（「電気関係の仕事を希望」と

「電気工学への興味」の合計）が増加してきている。景気 が上向きつつあることにより就職を第一目的とした学生が 減少したことや本学への入学生の偏差值が上昇傾向にある ことが主な原因であると分析する。

図 13 に 2005 年度における電気工学に対するイメージの 生成を示す。図 14 に 2005 年度における電気工学に対する 興味の向上を示寸。図 15 に 2005 年度における学習意欲の 向上を示寸。図 16 に, 図 13〜図 15 における肯定的な意見 の年度変化を示す。電気工学に対するイメージの生成にお ける肯定的な意見は, 2003 年度から 2004 年度で $3.0 \%$ 増加 し, 2004 年度から 2005 年度で $15 \%$ 増加した。電気工学に 対する興味の向上における肯定的な意見は，2003 年度〜 2004 年度で $1.0 \%$ 増加し，2004 年度～ 2005 年度で $17 \%$ 増加 した。学習意欲の向上における肯定的な意見は, 2003 年度

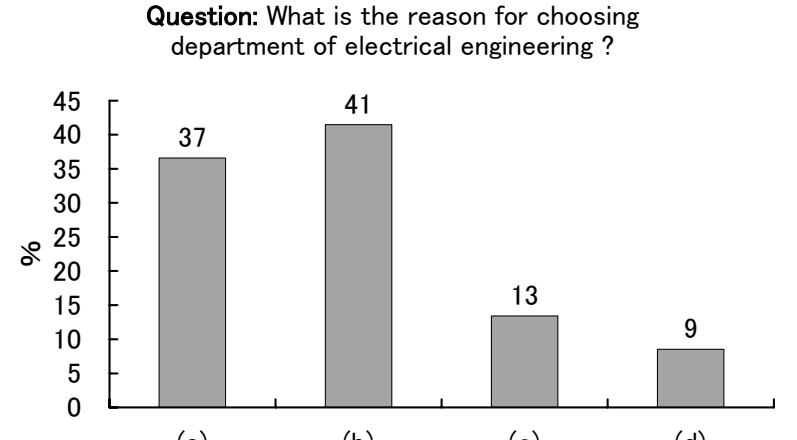

(a) (c)

図 11 電気工学科を選んだ理由 ((a)電気工学への興味, (b)電気関係の仕事を希望，(c)就職率の良さ，(d)その他)

Fig. 11. Reason for choosing department of electrical engineering ( (a) interest in the electrical engineering, (b) hope for job using electrical engineering, (c) high rate of employment, (d) other ).

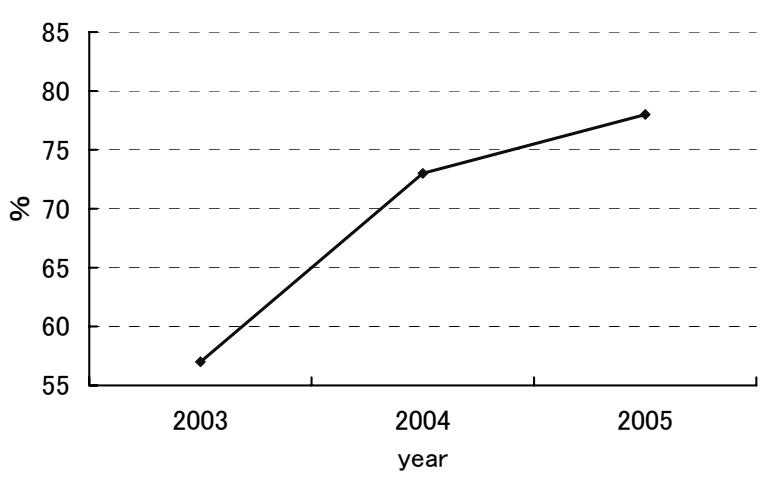

図 12 電気工学の習得を目的とした学生の変化

Fig. 12. Change of students who purpose to master electrical engineering.

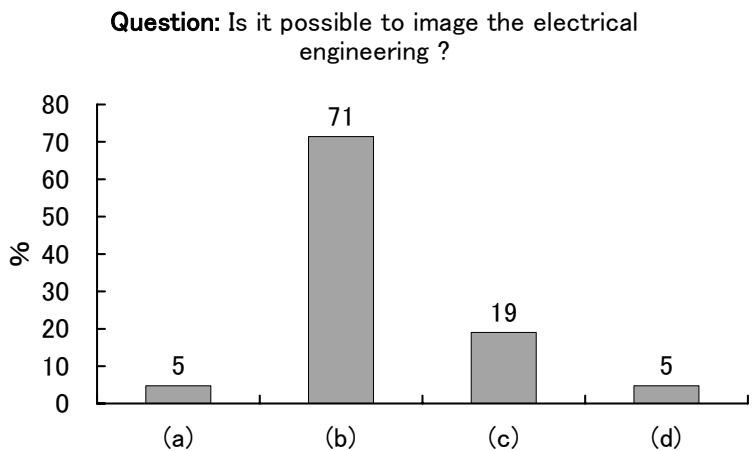

図 13 電気工学に対するイメージの生成 （a)肯定，(b)弱い肯定，(c)弱い否定，(d)否定）

Fig. 13. Generation of image for electrical engineering ( (a) affirmation, (b) weak affirmation, (c) weak denial, (d) denial ).

〜2004 年度で $1.0 \%$ 減少したが, 2004 年度〜2005 年度で $21 \%$ 増加した。年度を重㸚るごとに行ってきた, 講義における 授業内容の充実, 電気工学を意識した工作実習の採用とそ のブラシアップが，良い効果をもたらしていると分析する。 
Question: Did you take the great interest to the electrical engineering after attending the introduction to electrical engineering?

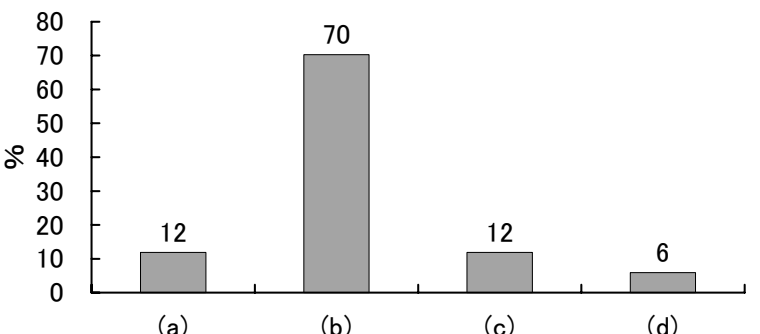

(a)

(b)

(c)

(d)

図 14 電気工学に対する興味の向上（(a)肯定, (b)弱い肯定，(c)弱い否定，(d)否定）

Fig. 14. Improvement in interest for electrical engineering ( (a) affirmation, (b) weak affirmation, (c) weak denial, (d) denial ).

Question: Did you have the motivation of learning after attending the intorduction to electrical engineering? (a)

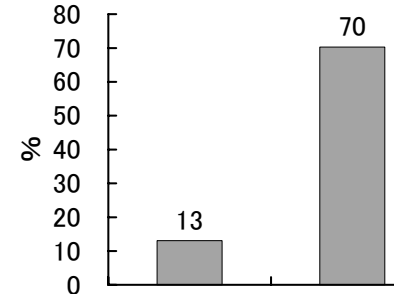

(b)

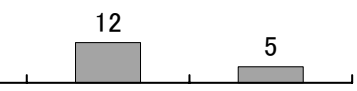

(c)

(d)
図 15 学習意欲の向上（(a)肯定，(b)弱い肯定， (c)弱い否定，(d)否定）

Fig. 15. Improvement in will to learn ( (a) affirmation, (b) weak affirmation, (c) weak denial, (d) denial ).
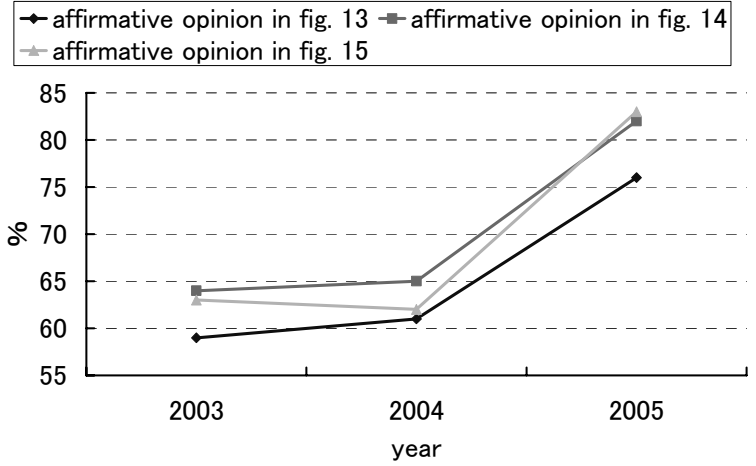

図 16 肯定的な意見の変化

Fig. 16. Change of affirmative opinion..

同じアンケートを電気工学概論の開講前後に実施していな いため，年次別の变化を具体的なデータを基に考察するこ とができない。しかし，受講生の入学時の意識レベルが大 体同じであると仮定すると，2005 年度の受講前後において 大きな変化があったことが推測できる。

\footnotetext{
$\langle 4 \cdot 3 \cdot 2\rangle$ 受講前と受講後の比較 図 17 に 2005 年度
}

Question: Did you make the best friends in the department of Electrical Engineering?

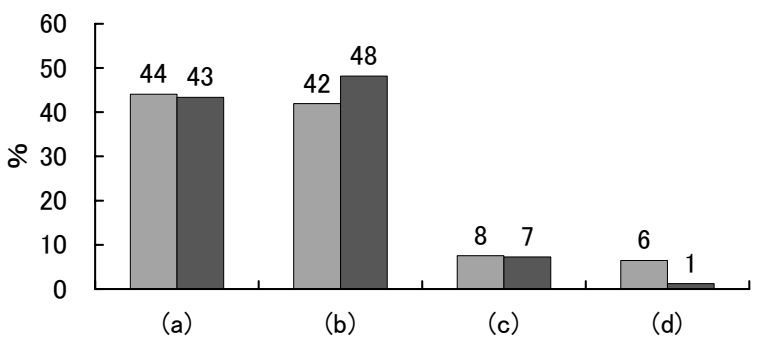

$\square$ before attending $\square$ after attending

図 17 新入生の結束 （(a)肯定，(b)弱い肯定, (c)弱い否定，(d)否定）

Fig. 17. Union of students ((a) affirmation, (b) weak affirmation, (c) weak denial, (d) denial ).

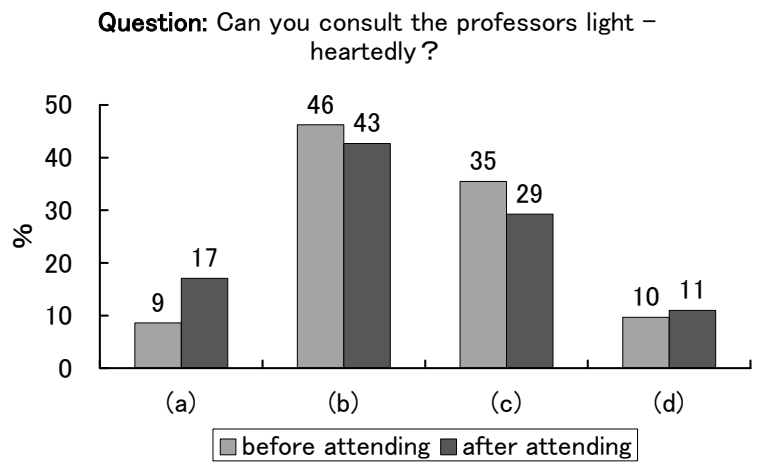

図 18 教員との関係改善 （(a)肯定，(b)弱い肯定， (c)弱い否定, (d)否定)

Fig. 18. Improvement on relation with teachers ((a) affirmation, (b) weak affirmation, (c) weak denial, (d) denial ).

Question: Can you explain the electirical engineering simply?

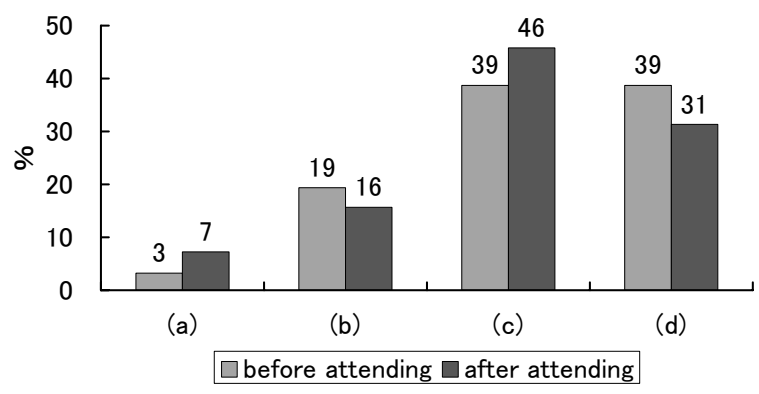

図 19 電気工学への理解の向上 ( (a) 肯定,

(b)弱い肯定， (c)弱い否定，(d)否定)

Fig. 19. Improvement in understanding to electrical engineering ((a) affirmation, (b) weak affirmation, (c) weak denial, (d) denial ).

における新入生の結束を示す。ここでの結束は，共同作業 を円滑に行える能力を測ったものではなく，何でも気軽に 相談できる交友関係の生成を意味する。肯定的な意見は, 受講前に比べ受講後は $5.0 \%$ 増加し，90\%を越えている。新 
入生の結束は, 十分行われている。図 18 に 2005 年度にお ける教員との関係改善を示す。肯定的な意見は，受講前に 比べ受講後は $5.0 \%$ 増加し，60\%を超えている。これらは， 少人数ゼミにおいて頻繁に行われた学生同士，または担当 教員との交流の効果と考える。

図 19 に 2005 年度における電気工学への理解の向上を示 す。受講後において, 肯定的な意見は，受講前に比べわず か $1.0 \%$ しか増加していないが, 完全な否定「そう思わない」 が減少しているため, 全体的には改善されている。これは, 電気工学概論の効果と分析するが, 更なる改善が望まれる。

\section{5. あとがき}

電気工学概論を開講して 3 年間が経過した。2003 年度は, 全体的な立ち上げ，指導体制の構築に終始した。2004 年度 は, 工作実習テーマの改善を行った。2005 年度は, FDを通 じた講義改善, 少人数ゼミで実施する工作実習における指 導方法のブラシアップに努めた。学生アンケートの結果か ら分かるように, 年度を負うごとに学生への教育効果が上 がってきている。しかしながら, 現状維持で済むような満 足な成果ではない。引き続き FD を通じて改善を行っていく 必要がある。今後は, 電気工学概論を通年科目として時間 数を増やし, 直流モータにおける電気的物理現象を考察さ せ, 電気工学における基本である電磁気学や電気回路の重 要性を認識させる内容を盛り込む予定である。

(平成 17 年 8 月 26 日受付, 平成 18 年 2 月 1 日再受付)

\section{文献}

(1) K. Ikeda and T. Kajiwara : "An Attempt at Educating Students before and after the Entrance Into the Department of Electrical Engineering of Fukuoka Institute of Technology", The Papers of Technical Meeting on Frontier in Education, IEE Japan, FIE-03-2 (2003) (in Japanese) 池田和生・梶原寿了:「福岡工業大学電気工学科入学生を対象とした 入学前後の取り組夕」, 電気学会教育フロンティア研資, FIE-03-2 (2003)

(2) T. Kajiwara, K. Ikeda, K. Kudou, K. Takeda, T. Yamane, and M. Morooka : "Development of Original Teaching Material And Utilization of CAE in Order to Respond to Various School Career oh The Students", The Papers of Technical Meeting on Frontier in Education, IEE Japan, FIE-04-24 (2004) (in Japanese)

梶原寿了・池田和生・工藤孝一・武田 薰・山根敬久・師岡正美 :「多 様な学習歴に対応する独自教材の開発と CAE の利用」, 電気学会教 育フロンティア研資, FIE-04-24 (2004)

( 3 ) K. Ohyama, T. Tujino, T. Kajiwara, K. Kudou, and M. Uchia : "Challenge to Education for Generating and Motivating at Department of Electrical Engineering, Fukuoka Institute of Technology”, The Papers of Technical Meeting on Frontier in Education, IEE Japan, FIE-03-24 (2003) (in Japanese)

大山和宏・辻野太郎・梶原寿了・工藤孝一・内田：「福岡工業大 学電気工学科における創成型・動機付教育への取組み」, 電気学会教 育フロンティア研資, FIE-03-24 (2003)

(4) K. Ohyama, K. Takeda, T. Kajiwara, K. Ikeda, K. Kudou, and T. Yamaguti : "Handicraft Training for Generating and Motivating at Department of Electrical Engineering, Fukuoka Institute of Technology, IEE Japan, FIE-04-30 (2004) (in Japanese)

大山和宏・武田 薰・梶原寿了・池田和生・工藤孝一 ・山口俊尚 :「福 岡工業大学電気工学科の創成型・動機付教育を目的とした工作実 習」, 電気学会教育フロンティア研資, FIE-04-30 (2004)

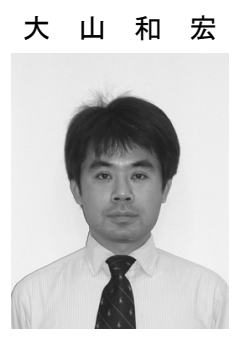

（正員） 1970 年 9 月 23 日生まれ。1998 年 3 月鹿児島大学大学院システム情報工学専攻博 士後期過程修了。同年 4 月より 1 年間ノッティ ンガム大学客員研究員。1999 年 4 月福岡工業大 学工学部講師, 2002 年 4 月同助教授となり現在 に至る。主として, 交流機のセンサレス制御に 関する研究に従事。

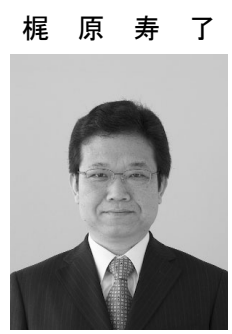

（正員） 1958 年 6 月 17 日生まれ。1981 年 3 月九州大学工学部電気工学科卒業。1986 年 3 月九州大学大学院総合理工学研究科エネルギ 一変換工学専攻博士後期課程修了。その後九州 大学大学院総合理工学研究科助手・同助教授を 経て, 2000 年 4 月福岡工業大学工学部電気工学 科教授。電気学会, 応用物理学会, 分光学会, 可視化情報学会会員。

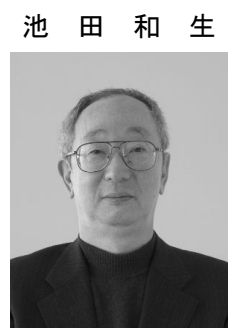

（非会員） 1946 年 2 月 7 日生まれ。1969 年 3 月京都大学理学部数学科卒業。1971 年大阪市立 大学大学院理学研究科修士課程数学専攻修了。 1973 年大阪市立大学大学院理学研究科博士課 程数学専攻退学。1973 年福岡工業短期大学講 師, 1975 年福岡工業大学講師を経て, 1996 年 福岡工業大学工学部助教授。現在に至る。主と して, 代数学に関する研究に従事。

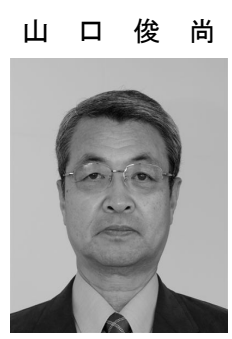

（正員） 1940 年 11 月 7 日生まれ。1969 年 3 月九州大学大学院修士課程電気工学専攻修 了。九州大学助手を経て, 1980 年 4 月福岡工業 大学助教授, 1982 年 4 月同教授, 現在に至る。 工学博士。この間, 軟質磁性材料, 磁気計測な どの研究に従事。1977 年電気学会論文賞。日本 応用磁気学会, 工学教育協会会員。

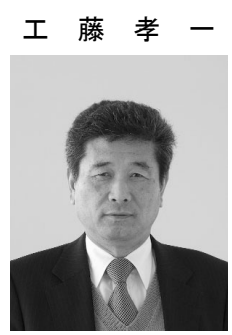

（正員） 1944 年 2 月 25 日生まれ。1972 年 3 月九州大学工学部工学研究科博士課程電気工 学専攻単位取得退学。1987 年 4 月福岡工業大学 電気工学科教授現在に至る。工学博士。主とし て放電プラズマに関する研究に従事。

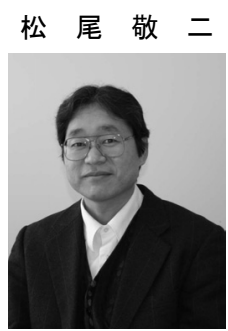

正員） 1960 年 2 月 28 日生まれ。1987 年 3 月九州大学大学院総合理工学研究科エネルギ 一変換工学専攻博士後期過程修了。同年 4 月よ り九州大学総合理工学研究科助手。1993 年 4 月福岡工業大学工学部助教授, 2001 年 4 月同教 授となり現在に至る。主として, 核融合を目指 した高温プラズマのレーザー計測に関する研 究に従事。 


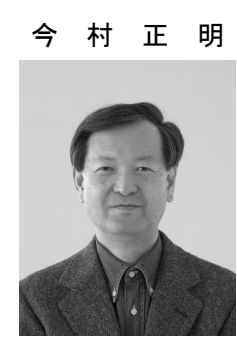

（正員） 1945 年 7 月 22 日生まれ。1969 年九 州大学工学部電気工学科卒業, 1977 年同大大学 院博士課程所定単位修得の上退学, 1979 年工学 博士。1977 年岐阜大学工学部助手, 1985 年福 岡工業大学工学部助教授, 1988 年同教授となり 現在に至る。主として, 分子線エピタキシャル による磁性半導体薄膜の光磁気特性の研究に 従事。

\section{柏 崎 英 徳}

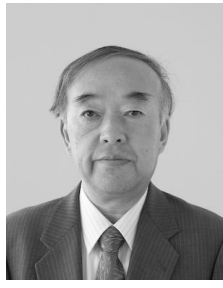

（非正員） 1949 年 2 月 25 日生まれ。1971 年 3 月福岡工業大学電気工学科卒業。2001 年 3 月佐 賀大学大学院工学系研究科エネルギー物質科 学専攻後期博士課程修了。1973 年 4 月福岡工業 大学電気工学科助手, 1994 年 4 月同大学講師を 経て, 2002 年 4 月同大学助教授。現在に至る。 主として,プラズマを用いた光源に関する研究 に従事。

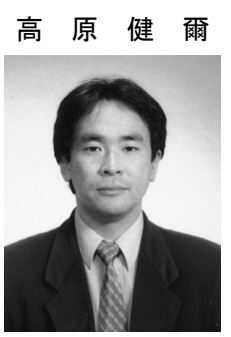

（正員） 1966 年 1 月 11 日生まれ。1997 年 3 月東京医科歯科大学大学院医学系研究科博士 課程単位取得退学。同年 4 月より室蘭工業大学 工学部電気電子工学科助手。2 005 年 3 月より福 岡工業大学工学部電気工学科助教授。現在に至 る。博士(工学)。

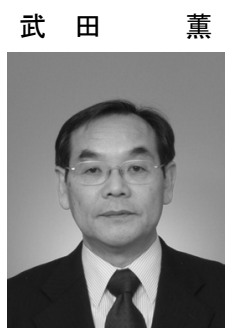

（正員） 1949 年 2 月 17 日生まれ。1972 年 3 月宮崎大学工学部応用物理学科卒業。1 1974 年 6 月福岡工業大学一般教養助手。1 1995 年 4 月福岡 工業大学工学部電気工学科講師。現在に至る。 主として，物性実験の研究に従事。

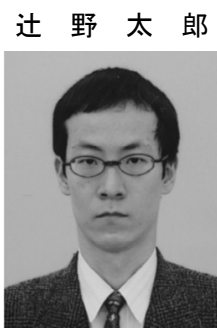

（非正員） 1965 年 12 月 17 日生まれ。1988 年 3 月大阪大学工学部卒業。1990 年 3 月同大学院工 学研究科博士前期課程修了。同年 4 月九州工業 大学情報工学部助手。1 1997 年 4 月大阪大学大学 院基礎工学研究科助手。1 999 年 4 月福岡工業大 学工学部助教授。現在に至る。博士 (工学)。 主として、ロバスト制御の研究に従事。

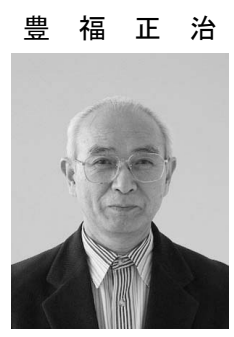

（正員） 1943 年 1 月 5 日生まれ。1963 年 3 月 福岡電子工業短期大学卒業。福岡電子工業短大 実験助手, 福岡工業大学助手, 講師を経て, 2002 年 4 月同大学助教授。現在に至る。2005 年 3 月佐賀大学大学院工学系研究科博士後期過程 (社会人) 修了。博士 (工学)。主として, 電 力工学, 静電気応用に関する研究に従事。静電 気学会。

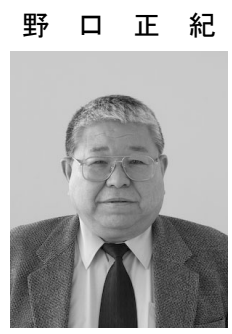

会員。

（正員） 1944 年 2 月 13 日生まれ。1964 年 3 月福岡電子工業短期大学電子工学科卒業。 1964 年 4 月福岡工業大学実験助手, 助手, 講師を経 て 2005 年 4 月同大学助教授。1 998 年 9 月から 2004 年 3 月まで, 九州大学大学院総合理工学府 訪問研究員。現在に至る。博士 (工学)。主と して, グロー放電プラズマへ適用するレーザト ムソン散乱計測法の研究に従事。応用物理学会

師 岡 正 美

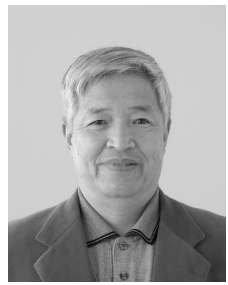

(正員) 1972 年 3 月九州大学大学院工学研究 科電気工学専攻修士課程修了。1973 年 3 月同博 士課程途中退学。1973 年 4 月福岡工業短期大学 講師, 福岡工業大学講師兼任。福岡工業大学助 教授を経て 1988 年 4 月同大学教授。現在に至 る。1994 年 4 月より 1 年間英国 Southampton大 学 Senior Fellow。工学博士。主として半導体中 の不純物拡散と欠陥に関する研究に従事。

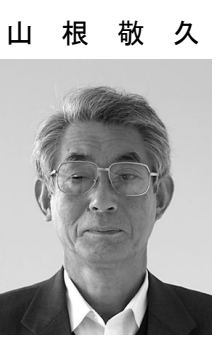

（正員） 1939 年 8 月 24 日生まれ。1965 年 3 月九州大学理学部物学科卒業。1968 年 3 月九州 大学大学院理学研究科修士課程物理理論専攻 修了。1972 年 3 月九州大学大学院理学研究科博 士課程物理理論専攻単位取得退学。1947 年 4 月福岡工業大学講師, 1976 年 4 月福岡工業大学 助教授。現在に至る。主として, 非線形現象に おけるカオスの統計性に関する研究に従事。 